\title{
THE SILURIAN TRILOBITES OF NEW SOUTH WALES, WITH REFERENCES TO THOSE OF OTHER PARTS OF AUSTRALIA.
}

By R. Etheridge, Junr.-Palæontologist to the Australian Museum, and Geological Survey of N. S. Wales-and John Mitchell, of the Public School, Narellan.

\section{PART I.}

(Plate xxv.)

\section{Introduction.}

In this and following papers, we purpose, as stated in a late communication to this Society, ${ }^{*}$ to give descriptions of the Silurian Trilobites of New South Wales, with passing references to those found in other parts of Australia. In the paper referred to we briefly mentioned the sources of our material. We shall endeavour to comprise the whole of the species of one genus within the compass of each paper, both as a means of comparison inter se, and with the view of convenient subdivision of the subject. Unless otherwise stated, the figured specimens are all taken from the collection of one of us.

We commence with the family Proetidæ.

Family PROETIDÆ.

Our knowledge of the Silurian Proetidæ of Australia is comprised in four descriptions of species by Sir F. McCoy, the late Messrs. de Koninck and Ratte, and one of us. The first-named naturalist described from the Wenlock shale of Broadhurst Creek,

* Proc. Linn. Soc. N. S. Wales, 1890, v. (2), Pt. 3, p. 501.

† Prod. Pal. Vict., Dec. III., I876, p. 17, t. 22, f. 10, 10a. 
near Kilmore, Victoria, a species under the name of Forbesia euryceps, which is peculiar from the great width of the cephalic shield, widely divergent genal angles, and the long spines attached thereto.

Prof. de Koninck referred three small pygidia from Yarralumla, N. S. Wales, to the British Proetus Stokesii, Murchison, ${ }^{*}$ but the only distinctive character which can be seized on is the presence of six or seven axis rings. These tails probably belong to one or other of the forms described later, and not to P. Stokesii at all.

The late Mr. F. Ratte described $\dagger$ a Trilobite from Bowning, referring it to Proetus ascanius, Corda, as figured by Barrande. This form will be discussed later on.

On two separate occasions a Proetus and a Cyphaspis have been described by one of us, the former as $P$. bowningensis, $\ddagger$ from the Lower Trilobite Bed at Bowning, the latter as C. bowningensis, $\$$ from the same locality and similar horizon. These will be forthwith re-described.

This, so far as we know, is an epitome of all that has been written on the Proetidæ of Australian Silurian rocks.

Genus Proktus, Steininger, 1831.

(Mém. Soc. Géol. France, I., p. 355.)

The groups which have been proposed within the wider generic term Proetus are the following :-

1. Pheton, Barrande, 1846. Pygidium with the pleuræ produced into spines, forming a fimbriated circumference.

2. Forbesia, McCoy, 1846. Genal angles produced into long spines; pleuræ of the pygidium segmented; glabella furrows present; and large tubercles terminating the neck-furrow.

* Foss. Pal. Nouv.-Galles du Sud, 1876, Pt. 1, p. 56.

† Proc. Linn. Soc. N. S. Wales, I. (2), p. 1066, t. 15, f. 1-4.

$\ddagger$ Proc. Linn. Soc. N. S. Wales, 1887, II. (2), Pt. 3, p. 439, t. 16, f. 4-6.

§ Proc. Linn. Soc. N. S. Wales, 1887, II. (2), Pt. 3, p. 438, t. 16, f. 3. 
3. Xiphogonium, Corda, 1847 . Pleuræ of the pygidium unsegmented ; nine segments to the thorax.

4. Celuus, Angelin, 1878. Two pairs of glabella furrows; twelve thoracic segments.

The non-acceptance of these terms by naturalists in general would seem to imply a difficulty in distributing the species under them. To us, however, Phaton appears a sound section of Proetus, and had any species occurred possessing its peculiar features we should have felt disposed to use it. Our inclination, also, would lead us to adopt Sir F. McCoy's Forbesia, were it not that the characters assigned appear to be more specific than even subgeneric. For instance, his $F$. euryceps does not show two of the most important characters used for its generic separation-the neck tubercles and glabella furrows. Some Proeti have segmented pygidial pleuræ, without the presence of genal spines, e.g., $P$. bohemicus, Barr.*; others again possess genal spines, but no glabella furrows, and a well-segmented pygidium, as, for instance, P. lepidus, Barr. $\uparrow$; a third species is provided with glabella furrows and genal spines, but the pleuræ of the pygidium are almost smooth; lastly, many species have well-developed neck lobes and genal spines, without the presence of neck lobes, and genal spines alone in the absence of glabella furrows, such as $P$. Prouti, Shumard, P. Rowi, Green, sp. $\ddagger$ Under these circumstances, Forbesia does not appear to have sufficient stability to form even a sub-genus.

Proetus Bowningensis, Mitchell (Pl. xxv., figs. 1, 1a-c). Proetus bowningensis, Mitchell, Proc. Linn. Soc. N. S. Wales, 1887 , I. (2), Pt. 3 , p. 439 , t. 16 , f. $4-6$.

Sp. Char.-Body subelliptical. Cephalic shield larger than the pygidium or thorax, equal in axial length to the pygidium, greater than the axial length of the thorax by the width of the neck ring and furrow; limb moderately wide, the margin thickened, flattened

* Syst. Sil. Bohême, 1852, I. Atlas, t. 16, f. 1-15.

† Syst. Sil. Bohême, 1852, I., t. 16, f. 28-30.

‡ Hall, Pal. N. York, Ill. Dev. Fossils, t. 21. 
in front of the glabella, striated at the side of the free cheeks; glabella conoid, obtusely pointed forwards, very moderately convex, no lateral furrows visible; neck furrow narrow, straight; neck segment rather wide, gently arched, sub-tumid at each extremity; axial furrows rather faint; facial sutures from the eyes to the frontal margin straight, thence outwards at an angle of about $60^{\circ}$, curved posteriorly, and cutting the posterior margin about the middle of the side lobes of the cephalic shield; fixed cheeks small, with large eye-lobes; eyes large and crescentic; free cheeks moderately large, with a well defined and striated margin; genal angles continued into stout spines, which reach to and include the fourth pleura of the thorax. Thorax of nine segments, with rather straight lateral margins, length equal to the combined width of the pleuræ; axis at its anterior end much wider than the side lobes, posteriorly they are equal, moderately arched: segments inclined slightly forwards; axial grooves distinct and narrow; pleuræ moderately arched, distinctly grooved, the grooves widest medially, diminishing towards the proximal and distal ends. Pygidium large, subelliptical or triangular, proportion of width to length as about $16: 14$; axis prominent, terminated distally somewhat abruptly and obliquely, twice as wide at the proximal as the distal end; segmentation faint, of eight or nine rings; axial furrows moderately distinct; pleuræ five, wider than the axis, less arched than those of the thorax, and the first three pairs distinctly furrowed; limb wide, striate, and slightly thickened.

Obs.-Additional specimens enable us to form a much better idea of the structure of this Trilobite than when it was originally described. The principal characters of the species are a conoid glabella, ill-defined glabella furrows, moderately large genal spines, a thoracic axis of nine segments, the axis of the pygidium of eight or nine, and the pleuræ of the same five in number. The original specimen of $P$. bowningensis figured was one in which the mutilated cephalic shield was in the form of an impression, and the pygidium as a decorticated relief. The test of this shield is beautifully ornamented with anastomosing lines, which on the genal angles and base of the spines become concentric 
and semi-imbricating. Similar sculpture exists in Proetus decorus, Barrande,* but the Trilobites do not otherwise agree. The normal number of ten thoracic segments is here departed from in favour of nine, a character which $P$. bowningensis possesses in common with the Bohemian species P. sculptus, Barr., $\dagger$ and the American Devonian P. longicaudus. Another peculiarity exists in the rather long genal spines, which extend to and include the fourth thoracic segment, a feature which is, however, exceeded by some Bohemian species, as well as by $P$. latifrons, McCoy, $\ddagger$ and one Australian form, $P$. australis, nobis. In $P$. latifrons, the genal spines reach as far as the sixth thoracic segment.

$P$. bowningensis does not closely resemble in its general specific characters any of the numerous Bohemian species, having too conoid a glabella and far too triangular a pygidium. Proetus parviusculus, Hall, $\S$ of the Hudson River Group, is much like our Pl. xxv. fig. 1c. about the glabella, and generally in regard to the whole cephalic shield, but the outline of the pygidium is much too semicircular.

From P. Rattei, nobis, the present species is distinguished by the absence of the longitudinal sulci on the glabella of that form, and from $P$. australis by the almost circumscribed condition of the basal lobes. The large plain glabella and wide diverging genal spines separate the Victorian P. euryceps, McCoy, $\|$ from our species at once.

Individuals from the Middle Trilobite Bed of the Bowning Series have a more prominent thoracic axis than those from the Upper Trilobite Bed, whilst the specimens obtained from the latter horizon have not been observed to possess anastomosing ornament.

\footnotetext{
* Syst. Sil. Bohême, 1852, I., Atlas, t. 17, f. 13.

† Syst Sil. Bohême, 1852, I., Atlas, t. 15, f. 1

$¥$ Forbesia, Brit. Pal. Foss., Fas. 1, 1851, p. 174.
}

$\S$ Hall and Whitfield, Report Geol. Survey, Ohio, II., Pt. 2, Pal., 1875, p. 109 , t. 4 , f. 18.

|| Prod. Pal. Vict., Dec. III., 1876, p. 17, t. 22, f. 10, $10 a$. 
Loc. and Horizon.-Bowning Creek, Bowning, Co. Harden (Coll. Mitchell); Middle and Upper Trilobite Beds of the Bowning Series-Upper Silurian (? Wenlock).

Proetus Rattei, sp.nov. (Pl. xxv., figs. 2, 2a-d).

Proetus ascanius, Ratte (non Barrande), Proc. Linn. Soc. N. S. Wales, I. (2), Pt. 4, p. 1066, t. 15, f. 1-4.

Sp. Char.-Body oval and flattened. Cephalic shield large, semicircular, and slightly convex ; limb wide, flattened, or slightly concave, with anastomosing striæ. Glabella short, square, and somewhat trilobed by two shallow longitudinal furrows, extending from the neck furrow to the front; basal pair of lateral furrows present, uniting the longitudinal furrows, and so dividing each lateral lobe into two; neck furrow distinct, narrow; neck segment wide, slightly convex about the middle; axial furrows rather faint, continuing round the front of the glabella; facial sutures anteriorly rather straight, and gently directed outwards to the margin, behind they cut the posterior margin at a distance from the glabella equal to that of one-third the width of the thoracic pleuræ; fixed cheeks very small; free cheeks large, very moderately convex; genal angles continued into stout spines, directed outwards slightly from the thorax, and extending as far as the fourth segment of the latter. Thorax of eight segments, the axis and pleuræ at the anterior end being about equal in width, but posteriorly the latter are much the wider; lateral margins straight; axis flat or very slightly arched; pleuræ flat and bent backwards towards their outer ends, terminating in rather claw-shaped spines, those of the third pleuræ apparently longer than the others. Pygidium relatively large, about three-fourths as long as the head-shield, subsemicircular; axis conical, of eight rings, the terminal ones very faint; contracting rapidly to the margin of the limb, thence continuing to the circumference as an acicular ridge, axial furrow distinct; pleuræ eight, distinctly furrowed, the furrows extending across the limb to the circumference; limb wide, marked off by a faint concentric depression, and faintly striated with concentric wavy striæ. 
Obs.-Proetus Rattei was figured and partially described by the late Mr. Felix Ratte, and provisionally referred to P. ascanius, Corda, but though the cephalic shield does to some extent agree with that of this species, as figured by Barrande,* there are differences which we consider sufficiently important to separate the two, and therefore beg to associate with it the name of our deceased friend.

The glabella in P. Rattei is much squarer than in P. ascanius, and approaches nearer to the hinder border of the limb. The longitudinal furrows also are longer, extending farther forward, whilst the basal lobe is smaller. At the same time, both Trilobites possess a great development of cephalic shield exterior to the glabella, and it was probably this, with the character of the furrows, which caused Mr. Ratte to make the reference to $P$. ascanius. Mr. Ratte appears to have copied Barrande's figures rather than the Australian fossils before him. P. Rattei is quite distinct from either of the other Australian species.

In some respects the pygidium of $P$. Rattei resembles that of $P$. decorus, Barr., $\uparrow$ but differs in being nearly semicircular instead of subtriangular. In the great proportionate size of the limb of the pygidium, our species approaches some forms of Bronteus; and in the short glabella and expanded cephalic shield it resembles Arethusina. On the other hand, the Proetiform characters of eight thoracic segments, and eyes close to the glabella, overbalance these peculiarities.

A similar acicular ridge to that at the posterior termination of the pygidium axis is also present in Proetus corycoeus, $\ddagger$ Conrad, a characteristic species of the Niagara Group. One of the most peculiar features in $P$. Rattei, and unobserved by us in any other species of the genus, is the enlargement of the pleural spine of the third thoracic segment. Is this a sexual character?

We have detected what we believe to be the larval condition. In the earliest stage the glabella is rudimentary, the eye exceed-

* Syst. Sil. Bohême, 1852, I., Atlas, t. 15, f. 41.

+ Syst. Sil. Bohême, 1852, I., Atlas, t. 17, f. 13. $\ddagger$ Hall, Pal. N. York, II., t. 67, f. 13. 
ingly small, the thoracic segments five in number, and the pygidium almost as large as the thorax and cephalic shield combined (Pl.xxv. fig. $2 d$ ). In the next stage the glabella is more fully developed, but the segments of the thorax remain the same in number.

Loc. and Horizon.-Bowning Creeek, Bowning, Co. Harden (Coll. Mitchell); Lower Trilobite Bed of the Bowning SeriesUpper Silurian (? Wenlock).

Proetus australis, sp.nov. (Pl. xxv., figs. 3, 3a-e).

Sp. Char.-Body oval or elliptical. Cephalic shield semi-elliptical; axial length greater than that of the thorax, and much greater than that of the pygidium. Glabella rather short, squarish or subrectangular, moderately prominent, equal in length to the pygidium; basal pair of lateral furrows distinct, and nearly circumscribing the basal lobes; neck furrow moderately distinct; neck segment wide, gently arched; axial furrows moderately distinct and continuous in front of the glabella; facial sutures anteriorly straight to the thickened edge of limb, thence incurving along it, behind cutting the posterior margins of the shield at about one-third their distance from the axial grooves; fixed cheeks small: eyes moderately large and reniform; free cheeks large and somewhat tumid; genal angles produced into very long and gently incurved spines, which completely embrace the thorax; limb wide, with a thickened edge, and striated on the under surface, the shield between it and the anterior edge of the glabella being much flattened. Thorax of eight segments, width twice that of the length ; axis moderately arched, tergal portion rather flat, almost twice as wide anteriorly as posteriorly; axial furrows distinct ; pleuræ gently directed or curved backwards, terminating distally in short claw-shaped spines. Pygidium semi-elliptical, twice as wide as long; axis short, half the length of the pygidium, more or less in the form of a truncated cone; pleuræ flat, five or six in number, faintly furrowed; limb striated ; surface presenting a faint appearance of granulation.

Obs.-Proetus australis is an interesting species, as by the nearly circumscribed basal lobes it shows a tendency to take on 
the Cyphaspis type, in which it agrees with P. decorus, Barr.,* $P$. striatus, Barr., $\dagger P$. archiaci, Barr. $\ddagger \quad I t$, however, retains its connection with Proetus by possessing eight thoracic segments.

The nearly complete isolation of the basal lobes also separates $P$. australis at once from $P$. bowningensis and P. Rattei.

The genal spines are of great length, embracing the whole of the thorax, a marked increase in this particular structure on that of $P$. bowningensis and P. Rattei. Herein $P$. australis agrees with $P$. Loveni, Barr., $\S$ and a similar length of spine occurs in $P$. Stokesii, Murchison, for McCoy $\|$ describes the genal spines of this species as extending to the pygidium, and thus embracing the whole of the thoracic segments.

Loc. and Horizon.-Bowning Creek, Bowning, Co. Harden (Coll. Mitchell); Lower Trilobite Bed of the Bowning SeriesUpper Silurian (? Wenlock).

In our next communication we shall treat of the Genus Cyphaspis.

\section{E X P L A N A T I O N O F P L A T E.}

\section{Proetus Bowningensis, Mitchell.}

Fig. 1. - A specimen wanting the free cheeks and genal spines.

Fig. la.-A similar one with less of the glabella preserved.

Fig. 1b. - A more or less complete individual.

Fig. 1c. - Side view of Fig. $1 b$.

\section{Proetus Rattei, Eth., fil., and Mitchell.}

Fig. 2. - The left half of a somewhat curved individual, showing the large third thoracic pleural spine, $\times 2$.

* Syst. Sil. Bohême, 1852, Atlas, t. 17, f. 13.

† Syst. Sil. Bohême, 1852, Atlas, t. 17, f. 46.

‡ Syst. Sil. Bohême, 1852, Atlas, t. 17, f. 42.

§ Syst. Sil. Bohême, 1852, Atlas, t. 16, f. 25 and 26.

\| Brit. Pal. Foss., 1851, Fas. 1, p. 174. 
Proteds Rattei, Eth., fil., and Mitchell (continued).

Fig. 2a.-Cephalic shield and portion of thorax, the lateral portions of the former rather displayed, $\times 2$.

Fig. 2b. - Remarkably small head of a young individual, $\times 5$.

Fig. 2c. - Pygidium showing the surface sculpture and acicular termination to the thoracic axis, $\times 2$.

Fig. 2d.-Larval form, $\times 5$.

Proetos australis, Eth., fil., and Mitchell.

Fig. 3. -A more or less perfect individual.

Fig. 3a.-Portion of a cephalie shield.

Fig. 3b.-A somewhat more perfect specimen than fig. 3, showing the long genal spines embracing the whole of the thorax, $\times 2$.

Fig. 3c. - A glabella showing small basal furrows, $\times 2$.

Fig. 3d.-A free cheek.

Fig. 3e. - Another free cheek, $\times 2$. 


\section{$2 \mathrm{BHL}$ Biodiversity Heritage Library}

Etheridge, Robert and Melo-Costa, Wanessa de. 1892. "The Silurian trilobites of New South Wales, with references to those of other parts of Australia. Part I." Proceedings of the Linnean Society of New South Wales 6, 311-320. https://doi.org/10.5962/bhl.part.29894.

View This Item Online: https://www.biodiversitylibrary.org/item/30437

DOI: https://doi.org/10.5962/bhl.part.29894

Permalink: https://www.biodiversitylibrary.org/partpdf/29894

\section{Holding Institution}

MBLWHOI Library

\section{Sponsored by}

MBLWHOI Library

\section{Copyright \& Reuse}

Copyright Status: NOT_IN_COPYRIGHT

This document was created from content at the Biodiversity Heritage Library, the world's largest open access digital library for biodiversity literature and archives. Visit BHL at https://www.biodiversitylibrary.org. 